\title{
PEMIKIRAN ZAKIAH DARADJAT ANTARA KESEHATAN MENTAL DAN PENDIDIKAN KARAKTER
}

\author{
Sri Indah* \\ Muqowim** \\ Radjasa $^{* * *}$
}

\begin{abstract}
Abstrak: This library research aimed to find the point of integration between mental health and character education. The dynamics of Islamic study is presecuted to develop the paradigm unity of Islamic study, exact sciences and humanities. This research try to contribute pedagogic by intergrating mental health science with Tafseer. Hopefully the intergration of mental health science gives the steady in conception in understanding of human dynamics. Integration with Tafseer meant to find originality in Islam. So this research is able to find the concept of comprehensive, holistic, in depth and applicable in the world of education. This is a qualitative research that used informaton from Al-Qur'an, Al-Hadis, books of mental health experts and character education experts. The documentation method was used to collect the data of research. This research try to reveal and to ta'shil the understanding of mental, mental health and tazkiyah nafs then aplicate this understanding into character education. The result of the research indicates that tazkiyah nafs is the point of integration between mental health and character education for building healthy and characteristic individual.
\end{abstract}

Keywords: Mental, Health Mental, Tazkiyah Nafs

\footnotetext{
${ }^{*}$ Mahasiswa Pasca Sarjana UIN Sunan Kalijaga Yogyakarta sriindah869@gmail.com

**Dosen Pasca Sarjana UIN Sunan Kalijaga Yogyakarta muqowim@uin-suka.ac.id

***Dosen Pasca Sarjana UIN Sunan Kalijaga Yogyakarta radjasa@uinsuka.ac.id
} 


\section{Pendahuluan}

7 akiah Daradjat adalah pakar psikolog muslim. Berkarier di Departemen Agama selama 30 Tahun sejak 1964, beliau menghabiskan sisa waktunya untuk mengajar dan menjadi guru besar ilmu Psikolog di UIN Syarif Hidayatullah Jakarta. Dari latar belakang pendidikan Zakiah Daradjat dalam bidang psikologi, maka pemikiran pendidikannya pun cenderung ke arah pendidikan terutama kesehatan mental. Adanya kecenderungan pemikiran yang demikian, agaknya menjadi perbedaan yang signifikan dari para pemikir pendidikan Islam yang lain.

Zakiyah Daradjat mencoba mengaplikasikan pendidikan dengan gaya yang sedikit agak berbeda, dia mencoba menarik akar pendidikan dimulai dari psikologinya, yaitu dari moral dan tingkah laku baik anak-anak bahkan remaja. Bagi Zakiah Daradjat, pendidikan Islam di Indonesia mempunyai tujuan yang jelas dan tegas. Menurut Zakiah, Islam memiliki tujuan yang jelas dan pasti, yaitu membina manusia agar menjadi hamba Allah yang shaleh dengan seluruh aspek kehidupannya yang mencakup perbuatan, pikiran, dan perasaan. Ungkapan diatas bila ditelusuri lebih jauh akan memiliki implikasi dan cakupan yang cukup luas. Membina manusia merupakan sebuah upaya untuk mengajar, melatih, mengarahkan, mengawasi, dan memberi teladan kepada seseorang untuk mencapai tujuan yang telah ditentukan. Pembinaan yang hanya memberikan pelajaran, latihan, dan arahan akan menciptakan manusia yang tidak berjiwa shaleh.

Sementara, pembinaan yang hanya memberikan pengawasan dan teladan akan menciptakan manusia yang kurang kreatif. Dalam pembinaan tersebut diarahkan kepada pembentukan seorang hamba Allah yang saleh. Untuk mencapai tingkatan yang saleh ini, penanaman nilai-nilai agama menjadi syarat utama. (Zakiyah Darojad, 1993:56) Tanpa penanaman nilai-nilai agama, pencapaian pembentukan hamba Allah yang saleh menjadi sangat jauh. Seorang hamba yang saleh berarti dia menyadari kedudukannya di dunia, yakni di samping sebagai khalifah Allah di bumi juga sebagai hamba Allah yang harus beribadah kepada-Nya. Kesadaran yang demikian 
ini akan muncul bila seseorang telah benar-benar mengerti, memahami, dan menghayati ajaran-ajaran agama Islam.

Selanjutnya, tujuan pendidikan menurut Zakiah juga agak berbeda dengan tujuan Pendidikan Nasional yang lebih menekankan pada aspek kecerdasan (intelektual) dan pengembangan manusia seutuhnya. Di samping itu, rasa tanggung jawab yang dikembangkan hanya mengarah kepada masyarakat dan bangsa. Oleh karena itu, dalam pelaksanaanya, Bagi peneliti, konsep pendidikan Islam dan kesehatan mental menurut Zakiah Daradjat, kiranya cukup menjadi sasaran untuk menggambarkan masalah fungsi pendidikan Islam dalam kesehatan mental, karena pembahasan tersebut dalam pandangan Zakiah Daradjat bukan saja berdasarkan kepada al-Qur'an dan hadits, tetapi juga berdasarkan pada pendapat pakar dan pemikiran modern tentang kesehatan mental. Dalam istilah pendidikan dan psikologi tema ini dapat berarti sebagai pembentukan pribadi muslim dan kepribadian bangsa.

Sebagai tokoh pendidikan islam zakiyah darajat sangat jeli dalam mengembangkan kemampuan melakukan pengamatan secara bertahap dan menyeluruh. Beliau berinteraksi dalam bidang kejiwaan maupun bidang pendidikan, agar supaya anak-anak dan remaja tersebut mulai mengenal duniannya sendiri maupun dunia luar. Dewasa ini, banyak terjadi penyimpangan tehadap kesehatan mental anak maupun remaja. Sekaligus para pendidik yang juga harus di jaga kesehatan mentalnya agar dapat membina serta memberi contoh yang baik untuk peserta didik. (Ari Gunawan, 1995:163)

Menurut kami, konsep pendidikan zakiyah darajat tidak hanya dilakukan pada anak atau remaja (peserta didik khususnya) melainkan juga bagi pendidik, karena pendidik merupakan orang pertama setelah orang tua mempengaruhi pembinaan kepribadian peserta didik. Sehingga menghasilkan akhlak pendidik yang baik begitupun untuk peserta didik selanjutnya.

Dalam ilmu psikolog menurut Zakiyah bahwa gangguan kejiwaan yang ikut mempengaruhi kondisi fisik seseorang dapat di 
telusuri melalui kajian psikolog yang di lakukan mengikuti ejaan Islam. Banyak yang di media social dan televise yang tidak sesui dengan nila-nilai agama, karena ada yang mengandung unsur kekerasan, seks sehingga dapat menumpulkan akal dan logika penontonnya.

Berangkat dari latar belakang masalah di atas, maka sangat pantas jika dilakukan sebuah penelitian terhadap pemikiran Zakiah Daradjat agar dapat dielaborasi lebih jauh. Untuk menyederhanakan tema tersebut, perlu kiranya dirumuskan pokok permasalahan yang ingin dikaji, yaitu bagaimana pemikiran Zakiah Daradjat tentang pendidikan Islam dan kesehatan mental serta integrasi pendidikan Islam dalam kesehatan mental dalam Al- Qur'an.

Menurut Zakiah Daradjat ada empat batasan tentangkonsep kesehatan mental. Konsep pertamaatau konsep sederhanamenurut Zakiah Daradjat, kesehatan mental adalah terhindarnya orang dari gejala-gejala gangguan mental/jiwa (neurose) dan dari gejalagejalapenyakit mental/jiwa(psychose).

Kesehatan mental merupakan salah satu bagian dari psikologi, yang dianggap salah satu bidang yang paling menarik diantara bidang-bidang lain dari psikologi, baik di kelompok para ahli ilmu kemanusiaan atapun dikelompok orang awam, sebabnya adalah bahwa untuk mencapai tingkat yang sesuai dalam kesehatan mental, merupkan yang dicita-citakan oleh semua orang. belum pernah terdengar seseorang menginginkan kehidupan psikologi yang tidak sehat. (Langgulung, 1986:3)

Pada dasarnya setiap orang pasti dan mendambakan kehidupan yang sehat, baik fisik maupun mental. Dalam aspek kehidupan mental, meskipun antara konsep normalitas dan abnormalitas hanya terdapat batas yang sangat tipis, namun antara pribadi yang normal dengan mental yang sehat dan pribadi yang abnormal dengan mental yang tidak sehat tetap dibedakan. Pribadi yang normal dengan mental yang sehat pada umumnya Hasan Langgulung, Teori-teori Kesehatan mental, bertingkah laku lebih kuat (serasi, tepat) dan bisa diterima oleh masyarakat pada umumnya. Sikap hidupnya sesuai dengan norma dan pola hidup 
kelompok masyarakat, sehingga ada hubungan antarpribadi dan antarsosial yang memuaskan. Selain itu, kehidupan psikisnya stabil, tidak banyak memendam konflik internal, suasana hatinya tenang dan jasmaninya selalu dalam kondisi sehat. (Kartono, 2000: 7)

Sebaliknya, pribadi abnormal dengan mental yang tidak sehat relatif jauh dari status integrasi dan mempunyai sifat "inferior" atau "superior". Di samping itu, pribadi abnormal umumnya dihinggapi gangguan mental, baik tunggal maupun ganda atau bahkan majemuk, dengan kelainan-kelainan mental berupa diliputi oleh banyak konflik batin, jiwanya tidak stabil, tidak mempunyai perhatian terhadap lingkungan sekitar, terpisah hidupnya dari masyarakat, dan selalu merasa gelisah dan takut. Secara fisik, pribadi abnormal dengan mental yang tidak sehat seperti itu biasanya juga sering sakit-sakitan.

Kesehatan sangat penting kita lakukan apalagi saat ini muncul virus atau covid-19 yang mengguncang di seluruh dunia yang awal adanya virus corona di daerah Wuhan China, akhirnya menyebar keseluruh dunia terutama di Indonesia, masyarakat kini pada panik dan takut menghadapi wabah penyakit akibat covid-19 ini, untuk mengantisipasi kecemasan atau kepanikan Tim Medis melakukan tindakan dengan cara PHBS perilaku hidup bersih dan sehat dan kesehatan mental lalu bagaimana kita dapat menjaga kesehatan mental kita? Saat Badan Kesehatan Dunia (WHO) merilis tips menjaga kesehatan mental di tengah wabah virus corona, banyak orang yang memuji di media sosial.Seperti yang dijelaskan oleh Nicky Lidbetter dari lembaga amal Anxiety UK, kecemasan karena ketidakberdayaan dan kegagalan untuk menoleransi ketidakpastian merupakan ciri-ciri khas pada banyak kasus gangguan kecemasan. Jadi dapat dipahami jika banyak individu yang sudah memiliki gangguan kecemasan akan merasa makin tertekan di masa seperti ini. "Kebanyakan kecemasan muncul karena rasa khawatir akan sesuatu yang belum mewujud dan menunggu sesuatu terjadi - virus corona menimbulkan kecemasan seperti itu tapi di skala yang besar," kata Rosie Weatherley, juru bicara untuk lembaga amal yang bergerak di kesehatan mental di Inggris, Mind. Anxiety Inggris 
menyarankan beberapa langkah berikut untuk mengatasi kecemasan: Menerima: Sadari dan terima segala ketidakpastian yang terlintas di pikiran Berhenti sejenak: Jangan bereaksi seperti biasanya. Jangan bereaksi sama sekali. Berhenti sejenak dan tarik nafas. Tarik diri: Katakan pada diri Anda bahwa ini hanya kekhawatiran Anda, dan tidak perlu mengkhawatirkan hal yang belum mewujud. Ini hanyalah perasaan dan pikiran. Jangan percaya semua yang Anda rasakan. Perasaan bukanlah pernyataan atau fakta. Lepaskan: Lepaskan pikiran dan perasaan. Semua akan berlalu. Anda tak perlu merespons setiap saat. Jelajahi: Jelajahi apa yang terjadi saat ini, karena sekarang, saat ini, semua baik-baik saja. Rasakan napas dan sensasi bernafas. Sadari tanah di bawah kaki Anda. Lihat sekeliling dan rasakan. Lalu alihkan perhatian Anda pada hal lain, pada apa yang harus Anda kerjakan dan bukan pada apa yang Anda khawatirkan. Lakukan hal yang perlu Anda lakukan dengan penuh kesadaran.

\section{Biografi Zakiah Daradjat}

Nama aslinya adalah Zakiah Daradjat, ia lahir pada tanggal 6 November 1929, di Bukittinggi, Provinsi Sumatera Barat. (Binar, 1997:117) Pendidikan awal yang pernah diduduki oleh Zakiah, selagi Zakiah berada dekat dengan orang tuanya dan saudarasaudaranya, yaitu jenjang pendidikan yang berawal dari sekolah Standard School Muhammadiyah Bukittinggi. Kemudian ke Kuliyatul Mubalihgat Muhammadiyah Padang Panjang, tamat pada tahun 1947. Bahkan meneruskan ke SMA bagian B TDR (Ilmu Pengetahuan Alam) pemuda, Bukit tinggi, tamat tahun1951. (Daradjat 1984: 63)

Zakiah bertekad meninggalkan kampung halamannya, pergi merantau ke Yogyakarta, untuk melanjutkan studinya ke perguruan tinggi. Setamat Doktoral I, Fakultas Tarbiyah PTAIN Yogyakarta, Zakiah pun mendapat tawaran untuk melanjutkan studi di Mesir. Di Mesir Zakiah memasuki Perguruan yang bernama "Ein Shams". Zakiah mengambil jurusan "Special Diploma for Education" University Fakulty of Education Cairo dapat diselesaikannya dan tamat tahun 
1958. Zakiah tidak berhenti sampai di situ saja, tetapi melanjutkan ke Magister Pendidikan Jurusan "Spesialisasi dalam Mental Hygiene" tamat pada tahun 1959. Terus sampai melanjutkan ke tingkat Doktor (Ph. D) Pendidikan, jurusan "Spesialiasi PsychoTerapy", selesai pada tahun 1964.

\section{Konsep Kesehatan Mental Menurut Pemikiran Zakiah Daradjat}

\section{Pengertian Kesebatan Mental}

Menurut definisi pertama ini orang yang sehat mentalnya adalah orang yang terhindar dari segala gangguan dan penyakit mental/jiwa. Yang dimaksud dengan gangguan mental/jiwa misalnya: sering cemas tanpa diketahui sebabnya, tidak ada kegairahan untuk bekerja, rasa badan lesu dan sebagainya. Konsep kedua, Zakiah Daradjat berpendapat bahwa kesehatan mental adalah kemampuan untuk menyesuaikan diri dengan diri sendiri, dengan orang lain dan masyarakat serta lingkungan di mana ia hidup. Konsep kedua ini lebih luas dan bersifat umum karena dihubungkan dengan kehidupan secara keseluruhan.

Kesanggupan untuk menyesuaikan diri itu akan membawa orangkepada kenikmatan hidup dan terhindar dari kecemasan, kegelisahan danketidakpuasan. Selain itu, orang akan penuh semangat dalam menghadapi hidup untuk meraih kebahagiaan konsep kesehatan mental yang ketiga menurut Zakiah disebut dengan pola pengembangan potensi secara maksimal. Beliau menjelaskan:

"Kesehatan mental adalah pengetahuan dan perbuatan yang bertujuan untuk mengembangkan dan memanfaatkan segala potensi, bakat dan pembawaan yang ada semaksimal mungkin, sehingga membawa kepada kebahagiaan diri dan orang lain, serta terhindar dari gangguan-gangguan dan penyakit jiwa".

Konsep tersebut mendorong orang untuk mengembangkan dan memanfaatkan segala potensi yang ada. Bakat yang tidak dapat tumbuh dan berkembang dengan baik akan membawa kepada 
kegelisahan dan pertentangan batin. Mungkin pula orang mendapat kesempatan untuk mengembangkan bakat dan potensi yang ada pada dirinya dengan baik, akan tetapi hal itu digunakannya untuk mengambil hak orang lain atau menyengsarakan orang, maka itu termasuk orang yang kurang sehat mentalnya.Konsep yang ketiga tersebut lebih menekankan pada pengembangan dan pemanfaatan segala daya dan pembawaan yang dibawa sejak lahir, sehingga benar-benar membawa manfaat dan kebaikan bagi dirinya sendiri maupun orang lain. Konsep yang keempat, Zakiah mengungkapkan bahwa: kesehatan mental adalah terwujudnya keharmonisan yang sungguh-sungguh antara fungsi-fungsi jiwa serta mempunyai kesanggupan untuk menghadapi problem-problem biasa yang terjadi dan merasakan secara positif kebahagiaan dan kemampuan dirinya.

Fungsi-fungsi jiwa seperti pikiran, perasaan, sikap, pandangan dan keyakinan hidup harus dapat saling membantu dan bekerjasama satu sama lain, sehingga tecapai keharmonisan yang menjauhkan seseorang dari perasaan ragu dan bimbang, serta terhindar dari kegelisahan dan pertentangan batin (konflik). Empat konsep kesehatan jiwa tersebut disempurnakan oleh Zakiah dalam pidato pengukuhan beliau sebagai guru besar untuk Kesehatan jiwa/mental di IAIN Syarif Hidayatullah Jakarta pada tahun 1984, beliau menyempurnakan definisi kesehatan mental sebagai berikut: "kesehatan mental adalah terwujudnya keserasian yang sungguhsungguh antara fungsi-fungsi kejiwaan dan terciptanya penyesuaian diri antara manusia dengan dirinya dan lingkungannya, berlandaskan keimanan dan ketakwaan serta bertujuan untuk mencapai kebahagiaan di dunia dan di akhirat". Hal tersebut dapat dijelaskan sebagai berikut: terwujudnya keserasian yang sungguhsungguh antara fungsi-fungsi kejiwaan ialah berkembangnya seluruh potensi kejiwaan secara seimbang sehingga manusia dapat mencapai kesehatannya secara lahiriah maupun batiniah. Selanjutnya terciptanya penyesuaian diri antara manusia dengan dirinya sendiri merupakan usaha untuk menyesuaikan diri secara sehat terhadap diri sendiri serta memanfaatkan potensi dan daya 
seoptimal mungkin sehingga penyesuaian diri membawa kesejahteraan dan kebahagiaan bagi diri sendiri maupun orang lain. Penyesuaian diri yang sehat terhadap lingkungan dan masyarakat merupakan tuntunan untuk meningkatkan keadaan masyarakatnya dan dirinya sendiri sebagai anggotanya. Artinya, manusia tidak hanya memenuhi tuntutan masyarakat dan mengadakan perbaikan di dalamnya tetapi juga dapat membangun dan mengembangkan dirinya sendiri secara serasi dalam masyarakat.

Hal ini hanya bisa dicapai apabila masing-masing individu dalam masyarakat sama sama berusaha meningkatkan diri secara terus menerus dalam batas-batas yang diridhoi Allah. Berlandaskan keimanan dan ketakwaan adalah masalah keserasian yang sungguhsungguh antar fungsi-fungsi kejiwaan dan penyesuaian diri antara manusia dengan dirinya sendiri dan lingkungannya hanya dapat terwujud secara baik dan sempurna apabila usaha ini didasarkan atas keimanan dan ketakwaan kepada Allah SWT. Dengan demikian, faktor agama memainkan peranan yang besar dalam pengertian kesehatan mental. Bertujuan untuk mencapai kehidupan yang bermakna dan bahagia di dunia dan akhirat adalah untuk mewujudkan kehidupan yang baik, sejahtera, dan bahagia bagi manusia secara lahir dan batin baik jasmani maupun rohani, serta dunia dan akhirat. Hal ini akan tercapai apabila manusia senantiasa berpegang teguh terhadap ajaran agama serta senantiasa patuh melaksanakan perintah Allah SWT serta menghindari segala larangan-Nya. Konsep tersebut memasukkan unsur agama yang sangat penting dan harus diupayakan penerapannya dalam kehidupan manusia. Selain itu konsep tersebut juga sejalan dengan penerapan prinsip-prinsip kesehatan mental dan pengembangan hubungan baik dengan sesama manusia.

\section{Faktor-faktor yang Memengarubi Kesehatan Mental}

Menurut Zakiah Daradjat ada 4 faktor yang memengaruhi Kesehatan mental antara lain: perasaan, pikiran/ kecerdasan, kelakuan dan kesehatan badan. Untuk lebih jelasnya akan dijabarkan sebagai berikut:( Tebba, 2005: 196) 


\section{Perasaan}

Menurut Zakiah Daradjat terdapat beberapa macam tekanan perasaan yang menyebabkan terganggunya kesehatan mental seseorang. Perasaan-perasaan tersebut antara lain:

\section{a. Rasa Cemas (Gelisab)}

Rasa cemas (gelisah) yaitu perasaan yang tidak menentu, panik, takut tanpa mengetahui apa yang ditakutkan. Misalnya seorang ibu akan cemas (gelisah) karena anaknya terlambat pulang sekolah. Pikirannya sudah bermacam-macam, takut kalau-kalau anaknya ditabrak mobil, diculik orang dan sebagainya. Dengan demikian terlalu banyak hal-hal yang menyebabkan cemas (gelisah) yang tidak pada tempatnya bila tidak berusaha memikirkan bagaimana mengatasi kesukaran tersebut.

Rasa cemas (gelisah) sangat wajar dimiliki oleh setiap orang. Akan tetapi rasa cemas (gelisah) yang berlebihan akan mengakibatkan kesehatan mental seseorang tersebut terganggu. Dengan demikian menurut Zakiah Daradjat setiap individu harus mampu mengontrol rasa cemas (gelisah) yang dialaminya sehingga tidak berlebihan yang selanjutnya akan membuat individu tersebut mendapatkan kesehatan mental dalam hidupnya.

\section{b. Iri Hati}

Seringkali orang merasa iri hati atas kebahagiaan orang lain. Perasaan ini bukan karena kebusukan hatinya seperti biasa disangka orang, akan tetapi karena ia sendiri tidak merasakan bahagia dalam hidupnya. Misalnya seorang ibu yang masih muda, cantik dan kaya merasa iri kepada suaminya karena anak-anaknya semua lebih senang kepada bapaknya daripada ibunya. Ia merasa bahwa suaminya kurang memperhatikannya. Si istri sering membandingbandingkan rumah tangganya dengan rumah tangga orang lain.

\section{c. Rasa Sedih}

Perasaan sedih ini banyak sekali terjadi. Banyak orang yang terlihat tidak pernah gembira dalam hidupnya. Sebabnya pun bermacam-macam, misalnya ada ibu yang merasa kesepian karena anak-anaknya sudah besar dan tidak banyak memerlukannya lagi. 
Kesedihan-kesedihan seperti itu dapat mengganggu kesehatan mental seseorang. Dengan demikian, seseorang yang ingin mendapatkan kesehatan mental harus mampu menghilangkan rasa sedih yang dialaminya dan mampu bangkit dari kesedihan tersebut dengan cara-cara positif sehingga kesehatan mentalnya tidak terganggu.

\section{d. Rasa Rendah Diri dan Hilangnya Kepercayaan kepada Diri Sendiri}

Rasa rendah diri dan tidak percaya kepada diri sendiri banyak sekali terjadi pada pemuda pemudi remaja. Rasa rendah diri dapat menyebabkan individu lekas tersinggung. Karena itu ia mungkin akan menjauhi pergaulan dengan orang lain, menyendiri, tidak berani mengemukakan pendapat, tidak berani mengambil suatu inisiatif. Lama kelamaan akan hilanglah kepercayaan kepada dirinya sendiri dan selanjutnya ia juga kurang percaya kepada orang lain.

\section{e. Rasa Marah}

Kata "marah" atau "amarah" diambil dari kata Arab "ammarah", artinya bersifat memerintah atau mendorong. "Marah" itu disebut "marah" karena dia merupakan wujud dorongan ke arah kejahatan. Karena itu, rasa marah yang tercela ialah marah yang mengarah kepada kejahatan. Kemarahan seperti ini biasanya terjadi bukan pada tempatnya atau tanpa ada alasan yang jelas, seperti mudah tersinggung atau merasa kurang diperhatikan. Orang seperti ini biasanya disebut pemarah. Tetapi marah yang pada tempatnya atau ada alasan yang jelas diperkenankan sekalipun tidak boleh berlebihan, karena bisa berdampak buruk.

Oleh karena itu seseorang harus mampu mengendalikan amarahnya sehingga ia tidak terjerumus oleh hawa nafsu yang dapat mengganggu kesehatan mentalnya dan selanjutnya ia pun dapat memperoleh kesehatan mental yang menjadi dambaan setiap orang.

\section{Pikiran/Kecerdasan}

Beberapa penelitian menunjukkan bahwa kecedasan itu bersifat diwarisi, artinya kecerdasan seorang anak dipengaruhi oleh ibu bapaknya atau oleh nenek moyangnya sesuai dengan hukum warisan/keturunan. Maka orang yang cerdas kemungkinan besar 
anaknya akan cerdas pula. Akan tetapi jika tidak mendapat kesempatan dan lingkungan yang baik untuk berkembang, maka kecerdasan itu tidak akan mencapai kemampuannya yang maksimal.

Mengenai pengaruh pikiran terhadap kesehatan mental memang besar sekali. Di antara gejala yang dapat dilihat yaitu, ketika seorang anak tidak dapat mengonsentrasikan pikiran tentang sesuatu hal yang penting, kemudian kemampuan berpikinnya menurun sehingga orang lain pun merasa seolah-olah ia tidak lagi cerdas, pikirannya tidak dapat digunakan dan sebagainya maka hal ini akan menyebabkan terganggunya ketenangan mental/jiwa pada anak tersebut. Terganggunya ketenangan mental/jiwa si anak biasanya disebabkan terutama oleh orang tuanya.

\section{Kelakuan}

Zakiah Daradjat berpendapat bahwa kelakuan dan tindakan seseorang yang tidak benar akan menyebabkan ketidaktenteraman hati atau kurang sehatnya mental/jiwa seseorang. Misalnya orang yang telah bertindak salah maka ia akan merasa tertekan atau merasa gelisah. Sehingga akan menyebabkan kesehatan mentalnya terganggu.

Selanjutnya sering terlihat ada seseorang yang suka mengganggu ketenangan dan hak orang lain, misalnya mencuri, menyakiti atau menyiksa orang lain, memfitnah dan sebagainya.

\section{Kesehatan Badan}

Zaman dahulu orang mengatakan bahwa mental yang sehat terletak dalam badan yang sehat, hal itu terbukti yaitu kesehatan badan memengaruhi kesehatan mental. Sehingga dua hal ini saling berkaitan yaitu apabila badan sakit maka mental pun akan terganggu, begitu juga sebaliknya apabila kesehatan mental terganggu maka fisik pun akan merasakan sakit.

Terjadinya tekanan-tekanan perasaan dalam kehidupan keluarga dapat disebabkan karena terganggunya kesehatan fisik seseorang. Sebab pada saat seseorang mengalami sakit pada fisiknya maka mentalnya pun akan terganggu yang membuatnya tidak mampu mengendalikan dirinya sendiri. Berdasarkan hal tersebut menurut Zakiah Daradjat setiap individu hendaknya mampu 
menyeimbangkan antara kesehatan badan dengan kesehatan mentalnya, karena dua keadaan ini saling berkaitan satu sama lain.

\section{Terapi Terhadap Orang yang Mengalami Gangguan Mental}

Menurut Zakiah Daradjat ada beberapa terapi yang dapat dilakukan terhadap orang yang mengalami gangguan mental antara lain: terapi individu, terapi jiwa (psikoterapi) dan terapi agama. Untuk lebih jelasnya akan diuraikan sebagai berikut:

\section{Terapi Individu}

Maksud dari terapi individu ini ialah terapi yang dilakukan secara perorangan (individu) yakni membantu seseorang yang mengalami gangguan mental dengan cara memberikan dorongan kepada mereka agar mau menolong diri mereka sendiri, terutama untuk mendapatkan ketenangan batinnya. Karena setiap individu yang hidup di dunia ini berpotensi untuk mengalami gangguan mental. Adapun tujuan akhir dari terapi individu ini ialah memberikan kebebasan kepada individu untuk memilih dan menentukan solusi akhir permasalahannya yang terbaik bagi kelangsungan hidup dan masa depan individu.

Seseorang yang memberikan terapi disebut sebagai terapis, sedangkan orang yang mendapatkan terapi disebut pasien/klien. Seorang terapis bertugas mengarahkan kliennya agar berusaha menghilangkan gangguan-gangguan dan konflik batin yang dialaminya. Langkah pertama yang dikerjakan oleh seorang terapis yaitu dengan melakukan pendekatan kepada kliennya agar memperoleh kepercayaan dari kliennya sehingga ia mau menceritakan permasalahan yang dialaminya dengan leluasa. Selanjutnya terapis mengarahkan klien untuk memilih jalan keluar yang paling tepat agar permasalahan yang dihadapi si klien dapat diatasi.

\section{Terapi Jiwa (Psikoterapi)}

Istilah psikoterapi mempunyai pengertian yang cukup banyak. Secara harfiah psikoterapi berasal dari kata psycho yang berarti jiwa 
dan therapy yang berarti penyembuhan. ${ }^{100}$ Jadi psikoterapi berarti penyembuhan jiwa. Psikoterapi juga diartikan sebagai pengobatan alam pikiran atau lebih tepatnya pengobatan dan perawatan gangguan psikis melalui metode psikologis. Istilah ini mencakup berbagai teknik yang bertujuan untuk membantu individu dalam mengatasi gangguan-gangguan emosionalnya dengan cara memodifikasi perilaku, pikiran dan emosinya sehingga individu tersebut mampu mengembangkan dirinya dalam mengatasi masalah psikisnya.

Psikoterapi umumnya dilakukan melalui wawancara terapi atau metode-metode tertentu, misalnya relaksasi, bermain dan sebagainya yang dapat merangsang individu yang mengalami gangguan mental/jiwa.

\section{Terapi Agama}

Terapi secara umum adalah salah satu cara pengobatan terhadap suatu gangguan atau penyakit yang dilakukan oleh seseorang yang terlatih dalam hubungan professional secara sukarela dengan tujuan untuk menghilangkan, mengubah atau menghambat gejala-gajala yang ada, mengoreksi perilaku yang terganggu dan menumbuhkembangkan kepribadian yang positif.

Berdasarkan pengertian tersebut maka dapat diketahui bahwa yang dimaksud dengan terapi agama ialah pengobatan terhadap suatu gangguan atau penyakit yang dilakukan oleh seseorang yang terlatih dalam hubungan professional secara sukarela dengan tujuan untuk menghilangkan, mengubah atau menghambat gejala-gejala yang ada, mengoreksi perilaku yang terganggu dan menumbuhkembangkan kepribadian yang positif dan cara pengobatan atau penyembuhan tersebut dilakukan dengan didasarkan pada tuntunan dan ajaran agama Islam yang sumber utamanya adalah Alquran dan Hadits.

Usaha penanggulangan gangguan jiwa ini dapat dilakukan sejak dini oleh yang bersangkutan, yaitu dengan mencari cara yang tepat untuk menyesuaikan diri dengan memilih norma-norma moral maka gangguan mental akan terselesaikan. Penyelesaian dengan 
memilih penyesuaian diri dengan norma-norma moral yang luhur seperti bekerja dengan jujur, resignasi (tawakal dan pasrah kepada Allah swt), sublimasi (mengubah rasa egoisme ke dalam bentuk tingkahlaku yang terpuji) dan kompensasi (mengimbangi kegagalan di satu bidang dengan mencapai sukses di bidang yang lain). Dalam hal ini dapat dilihat secara jelas bahwa agama dapat dijadikan sebagai terapi terhadap gangguan mental.

Kesehatan mental adalah suatu kondisi batin yang senantiasa berada dalam keadaan tenang, aman dan tenteram. Upaya untuk menemukan ketenangan batin dapat dilakukan antara lain melalui penyesuaian diri secara resignasi (penyerahan diri sepenuhnya kepada Allah SWT).

Menurut Zakiah Daradjat terapi agama ini berkaitan erat dengan keimanan, karena seseorang yang memiliki keimanan yang kuat maka ia tidak akan terpengaruh oleh apapun yang terjadi pada dirinya. Ia yakin bahwa keimanan itu akan membawanya kepada ketenteraman dan ketenangan batin. Oleh karena itu sesuatu yang diimani hendaknya harus selalu ada dan terpelihara dengan baik. Apabila yang diimani itu pada suatu ketika hilang atau tidak menenteramkannya lagi, maka di sini akan timbul kegoncangan perasaan yang kadang-kadang sampai menyebabkan terjadinya perselisihan baik dalam lingkungan keluarga maupun masyarakat. Orang yang mempercayai benda-benda keramat, pusaka dan sebagainya biasanya selama benda-benda tersebut masih ada padanya dan tampak memberi manfaat maka ia akan merasa tenteram tetapi apabila benda-benda tersebut hilang.

Menurut Zakiah Daradjat terapi agama ini berkaitan erat dengan keimanan, karena seseorang yang memiliki keimanan yang kuat maka ia tidak akan terpengaruh oleh apapun yang terjadi pada dirinya. Ia yakin bahwa keimanan itu akan membawanya kepada ketenteraman dan ketenangan batin. Oleh karena itu sesuatu yang diimani hendaknya harus selalu ada dan terpelihara dengan baik. Apabila yang diimani itu pada suatu ketika hilang atau tidak menenteramkannya lagi, maka di sini akan timbul kegoncangan 
perasaan yang kadang-kadang sampai menyebabkan terjadinya perselisihan baik dalam lingkungan keluarga maupun masyarakat.

Menurut Zakiah Daradjat objek keimanan yang tidak akan berubah manfaatnya dan tidak akan pernah hilang adalah keimanan yang ditentukan oleh agama. Dalam Islam terkenal dengan enam macam pokok keimanan. Semuanya memiliki fungsi sebagai terapi agama yang sangat bermanfaat bagi kesehatan mental seseorang. Enam macam pokok keimanan tersebut ialah: iman kepada Allah, iman kepada malaikat, iman kepada kitab-kitab suci, iman kepada Rasul-rasul, iman kepada hari kiamat dan iman kepada takdir. Untuk lebih jelasnya akan diuraikan sebagai berikut:

\section{Iman kepada Allah}

Menurut Zakiah Daradjat setiap orang memerlukan sesuatu di luar dirinya yang mempunyai kekuatan, kebijaksanaan dan kemampuan yang melebihinya. Keimanan adalah suatu proses kejiwaan yang tercakup di dalamnya semua fungsi jiwa, perasaan dan pikiran sama-sama meyakinkannya. Keimanan kepada Allah SWT mempunya arti yang sangat besar bagi kesehatan mental manusia. Dengan keimanan yang dimilikinya manusia dapat mengeluh, mengadu, meminta tolong, meminta perlindungan, meminta keadilan dan sebagainya disaat apapun dan di mana pun ia memerlukannya. Dengan demikian menurut Zakiah Daradjat iman kepada Allah SWT sebagai terapi agama terhadap orang yang mengalami gangguan mental dapat menenteramkan batin seseorang, karena dengan beriman kepada Allah SW'T setiap individu merasa memiliki tempat mengeluh dan mengungkapkan segala rasa hati. Dengan kepercayaan kepada Allah SWT manusia akan tertolong dalam melepaskan diri dari ikatan benda dan segala sesuatu yang bersifat material, dan akan dapat meringankan segala penderitaan batin yang terjadi dalam dirinya. Karena keimanan kepada Allah SWT merupakan unsur terpenting dalam hidup manusia.

\section{Iman kepada Malaikat}

Islam mengajarkan kepada umatnya agar mempercayai adanya malaikat bahkan termasuk dalam salah satu pokok (rukun) iman. 
Berbeda dengan manusia, malaikat mempunyai sifat taat dan patuh kepada Allah. Malaikat adalah contoh tertinggi dari kesucian dan kebaikan yang dapat dijadikan teladan bagi manusia.

Zakiah Daradjat berpendapat bahwa dalam pembinaan mental dan perkembangan kepribadian melalui terapi agama ini sangat diperlukan adanya seorang tokoh yang akan diteladani dan dicontoh. Tokoh tersebut dinamakan pribadi teladan (the ideal person). Proses untuk meniru segala sifat pribadi teladan tersebut dinamakan dengan identifikasi. Setiap individu memerlukan seseorang atau sesuatu yang tidak ada cela dan kekurangannya untuk dapat mengadakan identifikasi terhadapnya.

Menurut Zakiah Daradjat keimanan kepada malaikat sebagai terapi agama dapat menambah ketenteraman batin manusia yang mengalami gangguan terhadap kesehatan mentalnya, karena dengan percaya kepada malaikat sebagai pribadi teladan akan memberikan perkembangan yang baik bagi kesehatan mental manusia.

\section{Iman Kepada Kitab-kitab suci}

Berdasarkan penelitian dan pengalaman Zakiah Daradjat di klinik jiwa diketahui bahwa ketidakpercayaan seseorang terhadap Alquran dapat terjadi karena kurangnya pendidikan agama yang dilaluinya sejak kecil. Bahkan di antara mereka ada yang belum pernah melihat Alquran dan tidak sedikit yang belum pernah belajar bagaimana cara membaca Alquran. Sedangkan yang mengerti isinya sangat sedikit.

Menurut Zakiah Daradjat betapa pun buta hurufnya seseorang tentang Alquran, namun setelah mereka mengalami gangguan kejiwaan atau diserang oleh rasa cemas dan konflik jiwa yang tidak teratasi banyak sekali yang mengambil Alquran sebagai penenang hatinya. Dengan demikian Zakiah Daradjat berpendapat bahwa keimanan kepada Kitabullah sebagai terapi agama dapat menenteramkan batin dan melegakan mental/jiwa seseorang yang selanjutnya menjamin kesehatan mental orang tersebut. Karena dengan keimanannya tersebut seseorang akan terhindar dari prasangka-prasangka dan keragu-raguan yang mungkin 
menggelisahkan dan selanjutnya dapat membawa kepada kegoncangan mental/jiwa.

\section{Iman kepada Rasul-rasul Allah}

Iman kepada Allah SWT sangat penting sebagai terapi agama bagi kesehatan mental manusia. Kepercayaan kepada Allah SW'T harus dimanfaatkan atau digunakan dalam rangka mendekatkan diri kepada-Nya dengan mematuhi segala perintah dan menjauhi segala larangan-Nya. Iman kepada Allah SWT akan menjadikan manusia beriman kepada Rasul-rasul Allah, sebab apabila manusia tidak mempercayai bahwa Rasul-rasul atau Nabi-nabi tersebut merupakan utusan Allah maka mereka tidak akan dapat menjalankan agama. Selanjutnya mereka tidak akan sanggup mendekatkan diri kepada Allah SWT sehingga mengakibatkan datangnya kecemasan dan kegelisahan. menaati perintah-Nya dan menjauhi larangan-Nya.

Menurut Zakiah Daradjat, umat Islam wajib mempercayai Rasul-rasul Allah karena pokok-pokok keimanan yang dibawa oleh Rasul-rasul itu sama yakni mempercayai Allah SW'T dan mengabdi kepada-Nya saja. Apabila manusia tidak percaya bahwa Rasul-rasul itu utusan Allah maka ia tidak akan dapat menjalankan ajaran agama Islam, karena tuntunan yang dibawa oleh Rasul-rasul tersebut tersimpul dalam ajaran Islam. Selanjutnya manusia tidak akan sanggup untuk mendekatkan diri kepada Allah sehingga berakibat datangnya kecemasan dan kegelisahan. Oleh karena itu Zakiah Daradjat berpendapat bahwa iman kepada Rasul-rasul Allah akan menambah kesehatan mental dalam diri seseorang.

\section{Iman kepada Hari Kiamat}

Semua agama samawi percaya akan adanya hidup setelah mati yakni dimana akan ada perhitungan terhadap manusia atas segala tindakan dan perbuatannya di dunia. Di dalam hati setiap manusia baik dari zaman dahulu maupun pada zaman modern seperti saat ini pasti memiliki perasaan bahwa segala sesuatu di dunia ini tidak akan berakhir begitu saja. Karena dalam kehidupan di dunia masih belum tercipta keadilan yang sungguh-sungguh. Ada orang baik, jujur, ikhlas dan mengabdi kepada Tuhan tetapi hidupnya susah dan 
sering disusahkan bahkan ditipu oleh orang-orang jahat yang pandai menyembunyikan kejahatannya. Ada juga banyak manusia yang hidup sesuka hatinya, senang mengambil hak orang lain, suka berbuat maksiat dan sebagainya yang hidup mereka seolah-olah berada di alam bebas di mana tidak ada aturan, hukum dan moral sehingga menyebabkan gangguan terhadap kesehatan mental mereka.

Menurut Zakiah Daradjat dengan percaya kepada adanya hari kiamat akan tenanglah batin seorang mukmin karena ia dapat mempersiapkan dirinya untuk menjaga agar jangan sampai terkena bahaya yang terjadi pada hari kiamat. Dan hal ini akan membawa seseorang kepada kesehatan mental.

\section{Iman kepada Takdir}

Iman kepada takdir Allah merupakan pokok ajaran Islam yang sering menjadi sasaran kritikan orang-orang di luar Islam dan dari orang-orang Islam yang kurang mengerti ajaran agamanya. Mereka menyangka bahwa iman kepada takdir tersebut membuat orang menjadi lalai dan segan berusaha, malas mencari rizki dan sebagainya karena merasa bahwa segala sesuatu telah ditentukan lebih dahulu oleh Allah. Sebenarnya hal demikian akan dapat menjadi hal yang bertentangan dengan ajaran Islam.

Iman kepada takdir Allah tidak menghalangi manusia untuk berusaha. Karena ketentuan Allah ada yang mempunyai syarat dan adapula yang mutlak. Diantara yang mempunyai syarat misalnya hasil usaha manusia itu sendiri, apabila ia berbuat baik maka ia akan diberi hasil yang baik pula. Begitu pun sebaliknya apabila ia berbuat aniaya, dusta dan ingkar kepada Allah maka Allah tidak akan menyelamatkannya. Seseorang yang ingin mendapatkan kebaikan dalam hidupnya hendaknya berusaha berbuat baik dan mematuhi perintah Allah. Karena pada hakikatnya ketentuan-ketentuan tentang segala sesuatu itu memang di tangan Allah, akan tetapi manusia disuruh-Nya untuk berusaha sekuat tenaga dalam batasbatas hukum dan ketentuan-Nya pula. Di samping itu ada pula ketentuan Allah yang bersifat mutlak atau yang bersifat tidak ada hubungannya dengan usaha manusia, misalnya mengenai ketentuan 
umur, tempat mati dan sebagainya. Tidak ada satu orang pun yang dapat mengetahui kapan dan di mana seseorang tersebut akan mati, karena hal tersebut mutlak ketentuan dari Allah SWT.

Zakiah Daradjat berpendapat bahwa terapi agama dalam menangani masalah gangguan mental/jiwa sangat diperlukan. Karena di antara faktor-faktor penyebab dari gangguan-gangguan kejiwaan adalah adanya rasa kecewa karena kegagalan yang terjadi berulang-ulang atau karena kekecewaan yang sangat besar dan dapat juga disebabkan karena ia tidak percaya terhadap takdir Allah. Sehingga tidak sedikit orang-orang yang mengalami kegagalan dalam hidupnya baik dalam keluarga, sosial maupun ekonomi yang menyebabkan seseorang tersebut putus asa, patah hati bahkan apatis terhadap segala macam persoalan.

Berdasarkan pemaparan tentang enam macam pokok keimanan tersebut dapat disimpulkan bahwa pokok-pokok keimanan yang diwajibkan bagi umat Islam sangat penting artinya bagi kesehatan mental. Karena keimanan memupuk dan mengembangkan fungsifungsi jiwa dan memelihara keseimbangannya serta menjamin ketenteraman batin. Apabila manusia hidup berdasar rasio saja atau terlalu memuja ilmu pengetahuan dan melupakan unsur-unsur keimanan maka ia akan sering terbentur kepada kegelisahan dan kecemasan. Setiap orang akan selalu berusaha menghindar dari kegelisahan dan kecemasan dengan cara mencapai kebahagiaan hidup di dunia dan di akhirat. Untuk mencapai kebahagiaan hidup didunia dan di akhirat tersebut manusia memerlukan agama dengan intinya yaitu kepercayaan dan perbuatan (iman dan amal).

\section{Istilah Jiwa dan Mental}

Kata mental berasal dari bahasa Latin mens atau metis yang berarti jiwa, nyawa, sukma, roh, atau semangat. Karena itu, mental adalah hal-hal yang berkaitan dengan psycho atau kejiwaan yang dapat mempengaruhi perilaku individu. Setiap perilaku dan ekspresi gerak-gerik individu merupakan dorongan dan cerminan dari kondisi (suasana) mental (Kartono, 1989: 3). Secara sederhana, mental dapat dipahami sebagai sesuatu yang berhubungan dengan 
batin dan watak atau karakter, tidak bersifat jasmani (badan) (Bahasa, 1994: 646). Dalam bahasa Arab, kata jiwa diterjemahkan dengan nafs atau ruh. Dalam hal ini, para ahli bahasa sendiri menurut al-Anbarī bersilang pendapat. Ada ahli bahasa yang menyamakan nafs dengan ruh. Bagi mereka, kedua istilah itu memiliki satu makna, hanya saja nafs itu feminim (muannats) dan ruh itu maskulin (mudzakkar). Ada pula ahli bahasa yang membedakan kedua istilah itu dan menganggap ruh sebagai sumber kehidupan dan nafs sebagai sumber akal. Saat manusia tidur, maka nafsnya yang diangkat, sedang ruh-nya tidak diangkat. Bagi mereka, ruh hanya diangkat saat kematian (Al-Azhari, 2001: 3629) Perbedaan itu ternyata berlanjut dalam diskursus kejiwaan yang dikembangkan oleh ilmuwan-ilmuan muslim.

Ada ilmuwan yang menyamakan nafs dengan ruh dan ada juga ilmuwan yang membedakan nafs dengan ruh. Yang membedakan nafs dengan ruh ini memiliki pendapat yang beragam mengenai titik perbedaan antara kedua substansi itu. Mayoritas sarjana muslim menganggap ruh dan nafs merupakan dua istilah untuk satu makna yang sama. Meski begitu, sebagian sarjana muslim berpendapat bahwa kedua istilah itu merujuk pada dua entitas yang berbeda.... Pendapat yang menyamakan ruh dan nafs adalah pendapat mayoritas perawi ahlussunnah. Ruh dan nafs merupakan hal yang bisa dipergunakan secara bergantian. Istilah ruh dipergunakan ketika jiwa terpisah dari tubuh dan nafs biasanya diterapkan ketika jiwa berada dalam tubuh (Hasan, 2008: 291). Lebih jauhnya, nafs kadang dipakai sebagai istilah spiritual dan di pihak lain dipakai sebagai gabungan antara spiritual dan material: pribadi (self). Sebabnya, ruh adalah substansi spiritualitas manusia, bahkan diklaim sebagai inti keberadaan manusia itu sendiri (Hady, 2007: 179).

Dengan ruh itulah, manusia dinamakan manusia. Tanpa ruh, manusia hanyalah mayat yang berupa benda material semata. Oleh karena, dapat dipahami nafs itu bersifat spiritual dan memiliki dua dorongan yang menggerakkan, yaitu: ruhani (spiritual) dan jasadi (biologis). Lalu, dikarenakan nafs itu terkait dengan jasad, maka 
pengertian nafs bisa disederhanakan menjadi: sisi-dalam dari manusia. Dalam konteks al-Qur'an sendiri, kata nafs menunjuk dan lebih sesuai dimaknai dengan sisi dalam dari manusia kata mental berasal dari bahasa Latin mens atau metis yang berarti jiwa, nyawa, sukma, roh, atau semangat. Karena itu, mental adalah halhal yang berkaitan dengan psycho atau kejiwaan yang dapat mempengaruhi perilaku individu. Setiap perilaku dan ekspresi gerak-gerik individu merupakan dorongan dan cerminan dari kondisi (suasana) mental (Kartono, 1989: 3). Secara sederhana, mental dapat dipahami sebagai sesuatu yang berhubungan dengan batin dan watak atau karakter, tidak bersifat jasmani (badan) (Bahasa, 1994: 646). Dalam bahasa Arab, kata jiwa diterjemahkan dengan nafs atau ruh.

Dalam hal ini, para ahli bahasa sendiri menurut al-Anbarī bersilang pendapat. Ada ahli bahasa yang menyamakan nafs dengan ruh. Bagi mereka, kedua istilah itu memiliki satu makna, hanya saja nafs itu feminim (muannats) dan ruh itu maskulin (mudzakkar). Ada pula ahli bahasa yang membedakan kedua istilah itu dan menganggap ruh sebagai sumber kehidupan dan nafs sebagai sumber akal. Saat manusia tidur, maka nafsnya yang diangkat, sedang ruh-nya tidak diangkat. Bagi mereka, ruh hanya diangkat saat kematian (Al-Azhari, 2001: 3629). insan) (Baharudin, 2004: 94). Dalam bahasa moderen, sisi-dalam diri manusia dipopulerkan dengan istilah: jiwa (nafs; psikis) atau meminjam istilah Samsul Hadi: struktur kepribadian. Jiwa manusia tersebut memiliki struktur spiritual yang terdiri dari fakultas-fakultas spiritual (Hady, 2007: 176). Fakultas spiritual itu menurut al-Ghazali seperti dikutip Hanna Jumhana Bastaman (1997: 78)-terdiri dari empat macam, yaitu: al-qalb (hati), al-ruh (ruh), al- aql (akal) dan an-nafs (hawa nafsu; atau disebut juga al-hawa).

Dalam menanggapi struktur spiritual tersebut, para penulis muslim bersilang pendapat. Ada yang menganggap fakultas-fakultas itu adalah substansi yang berbeda, dan ada yang menganggap fakultas-fakultas itu sejatinya menunjuk pada satu substansi yang sama. Dalam hal ini, pendapat yang lebih logis adalah pendapat 
yang menganggap fakultasfakultas ini menunjuk pada satu substansi yang sama. Meskipun terdapat perbedaan pendapat mengenai perihal fakultas spiritual, akan tetapi seluruh penulis muslim sepakat jikalau semua fakultas itu bersifat immaterial atau spiritual, sehingga struktur itu berada dalam sisi dalam diri manusia-bukan jasad atau badan. Kesepakatan itu ternyata dikuatkan dengan al-Qur'an yang menganggap semua fakultas itu mengarah dan berada pada satu makna yang sama, yaitu: sisi-dalam diri manusia, meski masingmasing fakultas memiliki peran yang berbeda.

Kesimpulan nafs adalah sisi dalam diri manusia itu sesuai dengan penyimpulan Karzun terhadap definisi nafs yang dilontarkan para ulama. Dalam kesimpulan Karzun, seperti dikutip Pickhen (2005: 94) nafs adalah sesuatu yang berada dalam sisi internal manusia, yang mana esensi nafs itu tidak bisa dimengerti, ia mudah sekali diarahkan kebaikan dan keburukan, dan membawa beberapa karakter dan kualitas manusia yang memiliki efek yang termanifestasikan dalam kebiasaan manusia (human behaviour). Tidak heran, dalam psikologi sendiri, mental didefinisikan sebagai paduan secara menyeluruh antara berbagai fungsi-fungsi psikologis dengan kemampuan menghadapi krisis-krisis psikologis yang menimpa manusia yang dapat berpengaruh terhadap emosi dan dari emosi ini akan mempengaruhi pada kondisi mental. Dalam kata lain, mental dapat didefinisikan dengan yang berhubungan dengan pikiran, akal, ingatan atau proses yang berasosiasi dengan pikiran, akal dan ingatan. Yang mencakup pula, mudah lupa, malas berfikir, tidak mampu berkonsentrasi, picik, serakah, tidak dapat mengambil suatu keputusan yang baik dan benar, bahkan tidak mempunyai kemampuan untuk membedakan yang benar dan yang salah.

Dari sini, istilah mental itu terkait dengan, akal, jiwa, hati, dan etika (moral) serta tingkah laku. Satu kesatuan inilah yang membentuk mentalitas atau kepribadian (citra diri). tidak bisa dimengerti, ia mudah sekali diarahkan kebaikan dan keburukan, dan membawa beberapa karakter dan kualitas manusia yang memiliki efek yang termanifestasikan dalam kebiasaan manusia (human behaviour). Tidak heran, dalam psikologi sendiri, mental 
didefinisikan sebagai paduan secara menyeluruh antara berbagai fungsi-fungsi psikologis dengan kemampuan menghadapi krisiskrisis psikologis yang menimpa manusia yang dapat berpengaruh terhadap emosi dan dari emosi ini akan mempengaruhi pada kondisi mental. Dalam kata lain, mental dapat didefinisikan dengan yang berhubungan dengan pikiran, akal, ingatan atau proses yang berasosiasi dengan pikiran, akal dan ingatan. Yang mencakup pula, mudah lupa, malas berfikir, tidak mampu berkonsentrasi, picik, serakah, tidak dapat mengambil suatu keputusan yang baik dan benar, bahkan tidak mempunyai kemampuan untuk membedakan yang benar dan yang salah. Dari sini, istilah mental itu terkait dengan, akal, jiwa, hati, dan etika (moral) serta tingkah laku. Satu kesatuan inilah yang membentuk mentalitas atau kepribadian (citra diri).

\section{Jiwa Sehat: Menelusuri Validitas Indikator}

Sehat merupakan kondisi yang dikehendaki oleh setiap manusia, dan tidak ada satupun manusia yang berharap dirinya sakit. Hanya saja, kondisi sehat dan sakit merupakan kondisi kontinum dalam diri manusia (Dewi, 2012: 11). Efeknya, menetapkan batasan dan ukuran sehat dan sakit bukanlah perkara yang mudah, apalagi untuk melakukan evaluasi terhadap keduanya. Berangkat dari sini, kesehatan jiwa bukanlah ukuran statistic konstan, tapi ia adalah kondisi relatif dan dinamis. Artinya, dalam level antarpersonal, ia berbeda antara satu orang dengan yang lain; dan dalam level inter-personal, ia juga berbeda antara satu waktu dengan waktu yang lain (Ahmad, 1999: 37). Meski sehat bersifat kontinum, namun sehat itu diyakini dapat ditingkatkan dan dimaksimalkan. Keyakinan inilah yang melandasi kajian kesehatan mental, dari sejak dahulu hingga hari ini.

Sehat dan sakit merupakan kondisi bio-psiko-sosial yang menyatu dalam kehidupan manusia. Pengenalan konsep sehat dan sakit, baik secara fisik maupun psikis, merupakan bagian dari pengenalan manusia terhadap kondisi dirinya dan bagaimana penyesuaiannya dengan lingkungan sekitar (Dewi, 2012: 9). Para 
psikolog dan ahli kesehatan jiwa bersilang pendapat mengenai barometer kesehatan mental (Ahmad, 1999: 14). Sehat mental kadang dipahami dengan terbebas dari gangguan mental (mental disorders), atau terciptanya keseimbangan, terciptanya penyesuaian dan adaptasi, teraihnya kebahagiaan, dan ada pula yang berpendapat aktualisasi diri. Meski begitu, World Health Organization (WHO) mendefinisikannya dengan "suatu keadaan yang baik dimana seseorang menyadari kemampuannya, dapat menghadapi stress yang normal, dapat bekerja secara produktif dan menyenangkan, dan dapat berkontribusi dalam komunitasnya". Dengan kata lain, mental yang sehat, menurut Zakiah Drajat (dalam Gazi, 2010: 121), adalah mental yang terbebas dari neorosis dan psikosis; yang memiliki harmonitas pikiran, jiwa, dan perbuatan; yang mampu menyesuaikan diri (adaptasi); dan yang mampu mengembangkan minat dan bakat.

Berangkat dari uraian di atas, indikator mental sehat perlu ditetapkan. Kondisi mental sehat, menurut Rajih (1968: 512-3), diukur dengan mampu beradaptasi sosial, mampu beradaptasi pribadi, tidak mudah gundah, merasa bahagia, produktif, dan bertindak konstruktif. Menurut Brown (dalam Ahmad, 1999: 39), indikator pribadi bermental sehat adalah tidak berbohong, tidak melanggar aturan, tidak menguncing orang lain, tidak membunuh, tidak melakukan perbuatan yang mengancam kehidupan, dan melakukan yang ia anggap benar. Zahran dalam Ahmad (1999: 40), melihat pribadi yang sehat mental sebagai pribadi yang mudah adaptasi, berbahagia dengan diri sendiri, berbahagia dengan orang lain, mengaktualisasi diri, mampu menghadapi tuntutan hidup, integritas, berperilaku normal, dan hidup dengan damai. Sedangkan Kartono (1989: 11) menyebut pribadi bermental sehat apabila mampu menampilkan tingkah laku yang kuat dan bisa diterima masyarakat pada umumnya, sikap hidupnya sesuai norma dan pola kelompok masyarakat, sehingga ada relasi interpersonal maupun intersosial yang memuaskan. Jika diperhatikan, kebanyakan indikator kesehatan mental di atas berkutat seputar ranah individu dan sosial, dan tidak menyentuh persoalan spiritual, yakni 
kebutuhan manusia terhadap Sang Pencipta. Padahal, jiwa manusia adalah wadag pertemuan antara sisi spiritual dan sisi material manusia, dan berpusat oleh hati manusia yang berfungsi mewarnai dan menggerakkan sisi spiritual manusia. Hati sebagai pusat manusia sesuai dengan berita nabawi:

"Ingatlah, sungguh di dalam jasad itu terdapat segumpal darah. Jika segumpal darah itu baik, maka seluruh (perbuatan) jasad akan menjadi baik. Apabila segumpal darah itu rusak, maka seluruh (perbuatan) jasad akan menjadi rusak. Ingatlah, ia adalah hati." (Bukhari). Hati sebagai pusat jiwa manusia selalu berada dalam tarikan ruhani dan tarikan jasmani. Hal itu sesuai dengan makna bahasa dari kata qalaba itu sendiri, yakni: berbolak-balik dan berubah-ubah. (Fariz, tt: 17). Artinya, berbolak-balik antara pengaruh ruh dan jasad atau antara pengaruh aspek spiritual dan material manusia. Apabila pusat aktivitas jiwa manusia adalah hati yang bergerak di antara tarikan (pengaruh) ruh dan tarikan jasad, maka akal adalah pengaruh pengaruh ruh yang menahan jiwa dari ketergelinciran kepada tarikan-tarikan rendah material, sedangkan hawa adalah pengaruh jasad yang menarik dan mengelincirkan jiwa dari keluhuran tabiat ruh. Dengan begitu, pusat kekuatan tarikan kebaikan dan keburukan dalam jiwa manusia adalah: ruh dan jasad, yang interaksi kedua tarikan itu akan menentukan watak jiwa serta mengakibatkan terjadinya tingkah laku manusia (Ancok, Suroso, 1995: 158). Apabila jiwa dipengaruhi oleh kecenderungan rendah jasad, maka ia akan mengalami kejatuhan. Jika jiwa mengikuti kehendak luhur ruh, maka ia akan mengalami transformasi diri, dalam istilah Robert Frager, sampai tempat terdekat dengan Tuhan (Hady, 2007: 229). Tarikan ruh dan jasad dalam jiwa manusia mengakibatkan kekuatan keinginan (dalam istilah lain: emosional) dan pikiran (dalam istilah lain: rasional) berkembang dan beraktualisasi dalam hati manusia.

Di pihak lain, karena jiwa manusia bersifat spiritual, maka sifat dasar ini tidak bisa dilepaskan dari karakter hati manusia. Kemampuan hati mengendalikan tarikan ruh dan tarikan jasad itu akan melahirkan tiga dinamika jiwa manusia, yaitu: An-nafs 
la'ammarah bi as-Su' Dinamika jiwa ini cenderung pada tabiat jasad, mengejar dasar-dasar kenikmatan dan menarik qalb manusia untuk melakukan perbuatanperbuatan rendah sesuai dengan naluri insting, sehingga ia merupakan tempat dan sumber kejelekan dan tingkah laku yang tercela (Kalsyani, 1992: 115). Ini adalah jiwa yang tercela, yang tabiatnya adalah memerintahkan segala keburukan, dan tidak seorang pun mampu selamat darinya melainkan dengan taufiq Allah (Farid, 1985: 73). Hal itu sesuai dengan firman Allah, "Sungguh, nafsu itu selalu menyuruh kepada kejahatan, kecuali nafsu yang diberi rahmat oleh Tuhanku." (QS. Yusuf (12): 53) Annafs al-lawwamah

Dinamika jiwa lawwamah merupakan jiwa yang tidak tegar dalam satu keadaan, sering bolak-balik dan berubah-ubah, kadang ingat kadang lalai, kadang menuju Allah kadang berpaling dari-Nya, mencintai dan membenci, bahagia dan bersedih, ridha dan marah, taat dan bermaksiat (Farid, 1985: 72). Dinamika jiwa ini berada di antara jiwa la'ammarah bi alsu' dan jiwa mut\}mainnah. Jenis dinamika ini diketahui dari firman Allah, "Dan Aku bersumpah dengan jiwa yang amat menyesali (dirinya sendiri)." (QS. alQiyamah 75: 2) Dinamika jiwa lawwamah, menurut Ibnu Qayyim al-Jauziyah, ada dua jenis, yaitu: (1) jiwa lawwamah yang tercela, yaitu dinamika kejiwaan yang bodoh dan zalim yang dicela oleh Allah dan para malaikat, dan (2) jiwa lawwamah yang tidak tercela, yaitu dinamika kejiwaan yang mencela atas perbuatannya yang buruk dan berusaha untuk memperbaikinya (Jawziyah, 1992: 272). An-nafs al-mutmainnah Jiwa mutmainnah adalah jiwa yang tenang kepada Allah dan tenang dengan mengingat-Nya, kembali padaNya, merindukan bertemu dengan-Nya dan nikmat berdekatan dengan-Nya. Karena itu, Ibn al-,Abbas dalam Farid (1985: 70) mendefiniskan jiwa ini dengan jiwa yang percaya pada Allah. Dinamika kejiwaan ini telah diberi kesempurnaan cahaya hati, sehingga dapat meninggalkan sifat-sifat tercela dan tumbuh sifatsifat yang baik (Kalsyani, 1992: 116).

Dinamika jiwa inilah yang kelak di hari kiamat dipanggil untuk masuk ke dalam surga Allah dan menikmati berbagai kenikmatan di 
dalamnya, seperti firman Allah, "Wahai jiwa yang tenang, kembalilah kepada Tuhanmu dengan hati ridha lagi diridhai, maka masuklah ke dalam golongan hamba-hamba-Ku, masuklah ke dalam surga-Ku." (QS. al-Fajr 90: 27-30). Puncak dinamika jiwa manusia dibahasakan dengan: tenang (mutmainnah). Karenanya, puncak dinamika kejiwaan manusia ditandai dengan ketenangan dalam jiwa manusia. Semakin sempurna dinamika kejiwaan manusia, maka ketenangan semakin menguat dalam jiwa manusia. Sebaliknya, semakin lemah dinamika kejiwaan, maka jiwa manusia akan diserang dengan rasa kekuatiran yang berlebihan atau syahwat keinginan yang tidak terkontrol. Ketenangan jiwa manusia ditentukan pula oleh interaksi jiwa dengan pengaruh luhur ruh dan pengaruh rendah jasad. Apabila tarikan ruh semakin kuat terhadap jiwa manusia, maka manusia akan semakin tenang dan potensi akal akan bekerja dengan semakin baik dalam mengendalikan jiwa manusia. Akan tetapi, apabila pengaruh jasad yang semakin kuat, maka manusia akan semakin tidak terkontrol dan potensi hawa akan mengendalikan jiwa manusia. Potensi akal yang bekerja dengan ketenangan akan membentuk al-hilm dalam kejiwaan manusia, sedang potensi hawa yang dikendalikan ketenangan akan membentuk al-anah dalam kejiwaan manusia. Kualitas itu, dalam konsep islam, disuburkan oleh ketenangan jiwa manusia yang hanya diperoleh melalui jalan mengingat Allah (zikrullāh), seperti firman Allah, "Ingatlah, hanya dengan mengingati Allah-lah hati menjadi tenteram.” (QS. Al-Ra ${ }^{\text {ee }}$ 13: 28). Pengedepanan kata „dengan mengingati Allah" atas kalimat ,hati menjadi tentram ${ }^{\text {ee }}$ dalam konsep Bahasa Arab, menyiratkan makna: hashr (pembatasan). Konsekuensinya, jiwa manusia tidak akan tenang kecuali dengan mengingat Allah. Jiwa manusia adalah ruh yang bersifat spiritual. Logikanya, ketenangan jiwa itu akan terwujud dengan keterpenuhan kebutuhan spiritual. Pemenuhan kebutuhan jiwa akan sempurna dengan sesuatu yang bersifat spiritual. Dalam konsep Islam, pemenuhan kebutuhan jiwa spiritual dilakukan dengan menghadirkan Dzat Yang Maha Spiritual ke dalam jiwa manusia. Semakin intens manusia mengingat Tuhan, maka kehadiran Tuhan 
juga akan semakin intens hingga jiwa manusia semakin tenang. Sebaliknya, semakin sedikit manusia mengingat Tuhan, maka semakin kurang kehadiran Tuhan hingga manusia semakin tidak tenang. Berangkat dari uraian di atas, dimensi spiritual sangat signifikan dalam pencapaian kesehatan jiwa manusia tentu dalam perspektif islami. Karena itulah, Ahmad (1999: 512), saat mengkaji pemikiran menurut Ibn Qayyim Al-Jawziyah, menemukan indikator kesehatan jiwa yang mengakomodir spiritualitas jiwa manusia, yakni: ubudiyah, moderat, barakah (efektif), zikr, sidq (ketulusan sikap), ketenangan, ridha, ber-adab, berjiwa sosial dan menyempurnakan orang lain, optimis dan mengharap akhirat. Secara teoritis, barometer setiap kelainan tingkah laku individu ialah kondisi mentalnya. Mental sehat akan menentukan tanggapan individual atas dirinya terhadap setiap persoalan, dan kemampuan untuk beradaptasi, dan mental yang sehat pulalah yang menentukan apakah seseorang atau individu memiliki gairah hidup atau justru mereka pasif dan tidak bersemangat bahkan memiliki ketakutan untuk hidup (Daradjat, 1990: 16). Oleh karena itu, kesehatan mental bukan hanya persoalan mengenai terbebasnya individu dari sifat-sifat negatif, namun juga ditengarai dengan termanifestasikannya sifat-sifat positif dalam dirinya (Rajih, 1968: $512)$.

\section{Taqkiyah Nafs}

Upaya Pencapaian Mental Sehat Yang Berkarakter Kesehatan mental merupakan cabang ilmu yang membahas dan mengupayakan jiwa sehat. Jiwa sehat, dalam kajian ini, ditengarai dengan ketenangan jiwa (tuma'ninah). Ketenangan dalam jiwa manusia inilah yang akan mampu melahirkan karakter (khuluq) positif. Dalam hal ini, berita profetik menegaskan, "Kebajikan (albirr) itu yang membuat hati tenang dan membuat jiwa tenang, dan dosa (al-ism) adalah yang bergejolak dalam dada dan membuat gejolak dada." (Ahmad). Kebajikan adalah puncak karakter baik terhadap orang lain (al-ihsan). Karena itulah, berbuat baik kepada orang tua dalam teks hadis diperkenalkan dengan istilah: birr al- 
walidain, sedangkan dalam teks qurani disebut dengan istilah: ihsan. Kata ihsan ini, secara bahasa, berasal dari kata hasan, yang berarti kebaikan, sehingga ihsan dapat dipahami dengan berbuat kebaikan pada orang lain. Dalam berita profetik, ihsan-dilihat dari motif terhadap hukum Allah-memiliki dua kualitas, yakni: ihsan musyahadah dan ihsan muraqabah. Saat Nabi ditanya mengenai ihsan, maka Nabi menjawab, "Kau menyembah Allah seolah kau melihat-Nya. Jika kau tidak dapat melihat-Nya, maka Dia pasti melihatmu." (Muslim). Beribadah seolah melihat Allah itu melahirkan rasa harap segera bertemu Allah. Beribadah seolah dilihat Allah itu melahirkan rasa takut. Konversi istilah ibadah dalam hadis dengan ihsan pun tidaklah bermasalah. Pasalnya, ibadah adalah segala sesuatu yang disukai dan diridai Allah. Faktanya, Allah menyukai semua perbuatan baik. Pada dasarnya, birr (kebajikan) dan ihsan (kebaikan) merupakan sebentuk karakter baik yang berkualitas.

Jelasnya, dalam konsep islam, konsep birr sering disandingkan dengan shilah, dan ihsan disandingkan dengan 'adl. Silah adalah konsep hubungan kekerabatan antar saudara, dan birr adalah konsep hubungan kekeluargaan antara anak dan orangtua. 'Adl adalah konsep tindakan positif merespon seimbang dengan stimulus orang lain, sedang ihsan adalah konsep tindakan positif merespon yang lebih baik dari stimulus baik orang lain. Singkatnya, birr dan ihsan adalah kualitas maksimal dari karakter positif pribadi dalam bertindak baik pada obyek kebaikan. Dalam berita profetik di atas, kebajikan itu mungkin terjadi dalam horison jiwa yang tenang. Pasalnya, jiwa sehat menyukai kebajikan, dan kebajikan pun hanya mungkin dilakukan oleh jiwa yang tenang. Ringkasnya, terkait pendidikan karakter, maksimalisasi karakter positif dalam diri manusia hanya dapat diwujudkan dengan memanifestasikan ketenangan dalam dirinya. Jika jiwa manusia tidak tenang dalam hidup, maka ia tidak akan melahirkan kualitas positif dalam perilaku yang dilakukannya. Di sisi lain, pendidikan karakter merupakan sebentuk usaha menginternalisasikan dan menyamankan individu dengan karakterkarakter positif. Pendidikan karakter, menurut Frye 
(dalam Yaumi: 2014, 8) adalah the deliberate effort to helf people understand, care about and act upon core ethical value. Karena itu, dalam konsep pendidikan karakter, seseorang dapat memiliki karakter positif dengan mengolah tiga domain dirinya, yakni: pikiran, rasa dan raga. Urutan ini menunjukkan pula proses karakterisasi yang terjadi dalam diri seseorang.

Artinya, setiap individu akan terbiasa dengan karakter positif dimulai dengan memikirkan manfaat perbuatan, merasakan manfaat perbuatan itu, dan akhirnya perbuatan itu pun gampang dan mudah dilakukan (Said, 2010: 2-3). Semakin sering dilakukannya perbuatan tersebut, maka karakterisasi pun akan semakin sukses. Karakter (khuluq) merupakan istilah lain dari perilaku otomatis individu terhadap rangsangan atau obyek tertentu. Logikanya, luassempitnya cakupan obyek perbuatan otomatis individu sangat berpengaruh terhadap kapasitas, jenis dan kualitas karakter individu. Perilaku seorang individu yang membatasi cakupan karakter positif hanya pada ranah komunikasi intrapersonal dan komunikasi antar personal tentu akan berbeda dengan perilaku seorang pribadi yang meluaskan karakter hingga wilayah interaksi spiritual dengan Yang Maha Kuasa. Dalam persoalan inilah, konsep karakter dapat berjumpa dengan konsep akhlak, atau adab, dalam diskursus ilmu keislaman. Artinya, konsep karakter, dalam pendidikan karakter, bertemu dengan konsep adab dalam ranah interaksi intrapersonal dan antarpersonal, namun mereka berpisah dalam wilayah interaksi spiritual yang sejatinya menjelaskan pisahkumpulnya dasar filsafat keduanya. Sebabnya, adab (karakter positif), dalam diskursus ilmu akhlak, mencakup dan diukur dengan empat dimensi, yakni: dimensi interaksi dengan Allah, dimensi interaksi dengan diri sendiri, dimensi interaksi dengan orang lain dan dimensi interaksi dengan alam semesta. Oleh karena itu, karakter positif dalam islam tidak hanya diukur dari perilaku baik terhadap orang lain, namun dipengaruhi dan diukur melalui keseimbangan interaksi empat dimensi tersebut. Artinya, orang berkarakter baik, dalam konsep ilmu akhlak, tidak hanya diukur dengan mampu bersosialisasi secara baik dengan orang lain saja, namun baiknya seseorang juga 
ditentukan dengan baiknya bersikap terhadap hukum Allah; dan begitu pula sebaliknya.

Solusi persoalan merosotnya humanitas manusia adalah menciptakan kembali ketenangan jiwa manusia. Jelasnya, ketenangan jiwa melahirkan karakter positif, dan karakter positif merupakan solusi kerisauan futuristik pendidikan manusia. Ketenangan mental, dalam konsep keilmuan islam, hanya dapat dicapai dengan zikrullah (mengingat Allah) (QS. Al-Ra ${ }^{e e}$ 13: 28). Zikrullah itu sendiri ada dua jenis, yaitu: mengingat Dzat Allah dan mengingat hukum Allah. Mengingat Dzat Allah itu dicapai dengan aktivitas seperti mengucapkan hamdalah, tasbih dan lain-lain. Mengingat hukum Allah itu dengan melakukan perbuatan atau menjauhi perbuatan dalam kerangka menyelaraskan diri dengan perintah Allah.

Persoalannya, mengingat Dzat Allah tidak selalu diikuti mengingat mengingat hukum Allah, tapi mengingat hukum Allah mengharuskan mengingat Allah. Artinya, seseorang setelah mengingat Allah terkadang tidak dapat mengingat atau terlambat mengingat hukum Allah. Karena itu, persoalan mengingat hukum Allah itu manifestasinya lebih diharapkan dalam upaya peraihan ketenangan jiwa daripada mengingat Dzat Allah. Mengingat hukum Allah akan dapat diraih sempurna dengan memahami hukum Allah dalam konteks realitasnya yang tepat. Artinya, kita mesti mampu mengejawantahkan hukum Allah setepat mungkin dengan tuntutan ruang dan waktu dari setiap episode kehidupan kita. Hukum Allah yang dibutuhkan realitas kita hari ini tidak boleh ditunda hingga esok hari. Hukum Allah yang dituntut realitas kita esok hari tidak boleh diajukan hari ini. Semua berjalan sesuai kebutuhan sewaktu. Pemahaman inilah yang diperkenalkan Al-Ghazali dalam AlMaqdisi (1979: 16) dengan istilah: ilm mu amalah, yakni: ilmu mengenai interaksi seorang hamba dengan Allah. Lebih jauhnya, Al-Ghazali menyebut dimensi interaksi hamba dengan Allah itu ada tiga, yaitu: keyakinan (iłtiqad), melakukan perbuatan (fi `l) dan meninggalkan perbuatan (tark). Tiga dimensi itu sejatinya dapat disederhanakan menjadi dua ranah, yakni: ranah teori (i tiqad) dan 
ranah praktik (fi’l dan tark). Ranah teori menuntut aktivitas memahami hingga mencapai tingkat meyakini terhadap dua obyek aktivitas, yaitu: hukum Allah dan realitas. Bentuk teori inilah yang akan memproduksi aksi sewaktu pemiliknya. Artinya, pemahaman valid aturan Allah terhadap persoalan sewaktu dan terhadap realitas sewaktu akan melahirkan tindakan praktis yang sesuai dengan tuntutan realitas sewaktu. Pemahaman itu pun harus melahirkan keyakinan. Keyakinan ini yang melahirkan semangat dan niat untuk melakukannya. Karenanya, selarasnya dua ranah tersebut semakin memudahkan seseorang mengejawantahkan hukum Allah dengan baik sesuai tuntutan realitas sewaktunya. Di sisi lain, ranah praktis itu sejatinya memuat dua hal, yakni: melakukan (fi 'l) perbuatan positif dan meninggalkan (tark) perbuatan negatif. Terbentuknya karakter positif menuntut adanya perbuatan positif, dan perbuatan positif akan sukses dengan meniadakan perbuatan negatif. Karena itu, ada pesan propetik, "Jika aku melarang kalian dari sesuatu, maka kalian jauhilah. Dan jika aku memerintahkan satu perintah, maka lakukanlah sekuat kemampuan kalian." (Bukhari). Paruh pertama pesan propetik itu memuat dimensi tark, dan paruh kedua memuat dimensi fi ${ }^{\prime}$. Di sini, teraihnya kuantitas perbuatan positif ditentukan pada keseriusan dan kemampuan manusia, sedangkan perbuatan negatif diperintahkan dihindari secara total, tanpa memperhatikan kemampuan manusia. Logikanya, jika manusia terbebas dari hama perbuatan negatif (takhalli), maka ia akan subur dengan perbuatan positif (tahalli). Inilah konsep lama dalam ilmu kejiwaan muslim. Mental sehat, dalam diskursus ilmu kesehatan mental kontemporer, dapat diraih dengan tereliminasinya gangguan kejiwaan dan tersalurnya aktualisasi diri. Secara umum, teori peraihan kesehatan mental (dalam Nugroho, 2011: 21-23) dalam psikologi moderen ada lima model, yaitu: (1) teori simptomatisyang memandang pencapaian kesehatan jiwa dengan indikator bebasnya individu dari berbagai gangguan kejiwaan; (2) teori adaptasi yang berorientasi pada kemampuan individu untuk menyesuaikan secara positif terhadap lingkungan alam, sosial dan kultural; (3) teori aktualisasi diri (self actualization) yang 
berorientasi pada pengembangan potensi pribadi secara maksimal sebagai bentuk tampilan kesehatan mental, seperti citra diri positif, percaya diri, dan lain-lain; (4) teori spiritualisasi yang berorientasi pada penguatan rohani atau agama dan nilai-nilai spiritual serta moral pada diri manusia sebagai indikator dalam pengembangan kesehatan jiwa individu, dan (5) teori psiko-etis, yang mengukur kesehatan mental dengan berkembangnya perilaku etis sosial dan altruisme, seperti suka menolong, rendah hati, keteladanan, pengorbanan dan lain-lain. Penyehatan mental manusia, dalam diskursus keilmuan islam, dibahasakan dengan istilah: tazkiyah nafs (QS. 62: 2).

Tazkiyah, dalam Bahasa Arab, memiliki akar kata: zakā-yazkuzakwan. Menurut Ibn Manzur (t.th: 358), kata zakā bermakna, yaitu: penyucian (tahārah), pengembangan (namā'), keberkahan (barākah) dan pujian (madh). Semua makna zakā itu, menurut Ibn Fariz (t.th: 17), merujuk kepada satu makna dasar: bertumbuh dan bertambah. Meski ia seolah ragu dan menambah makna dasar lain, yaitu: membersihkan (t.th: 17). Sedangkan, Kata tazkiyah bentuk nomina dari kata zakkā-yuzakkī, dengan tambahan tasydīd. Tambahan itu, dalam konsep Bahasa Arab, berfungsi mentransitifkan kata intransitif sekaligus memuat makna diulangulang. Konsekuensinya, keberhasilan tazkiyah itu perlu waktu panjang, cara yang bisa jadi beragam dan dilakukan berulang-ulang, bukan sebuah proses seketika sekali aksi dengan hasil maksimal. Beragamnya makna dasar kata tazkiyah di atas sejatinya tidak terpisah satu sama lain. Makna-makna itu membentuk satu konfigurasi makna yang lengkap dan mendalam. Lebih jelasnya, dalam makna menyucikan, manakala seseorang sedang menyucikan sesuatu, maka sejatinya ia sedang menambahkan kualitas pada sesuatu itu. Ilustrasinya, orang yang membersihkan hama dari ladang yang akan ditanami, sejatinya ia sedang menambah kualitas tanah untuk diberi tanaman. Seperti itu juga, saat Nabi menyucikan, maka dia sedang menumbuhkan kualitas dalam obyek yang disucikan Nabi. Inilah mungkin yang menjadi dasar istilah tazkiyah menjadi pilihan dalam setiap aktivitas agama yang bersifat 
menyucikan di satu sisi dan mengembangkan di sisi yang lain. Tazkiyah nafs, dalam konsep Islam, sejatinya tidak dibatasi dengan metode tertentu. Sebabnya, konsep ini tidak dibahas secara detail dalam Al-Qur'an dan Al-Hadis, namun hanya disinggung secara global. Berbeda dengan konsep semisal warisan, yang konsep detailnya dijelaskan terperinci dalam Al-Qurean. Dalam persoalan ini, mekanisme dan prosesi tazkiyah dikembalikan pada budaya dan bahasa yang berkembang dalam sosio-kultur manusia. Konsekuensinya, peraihan kesehatan jiwa dan pembangunan karakter pun dapat mengakomodir seluruh metode, media dan alat ukur yang ditemukan manusia, baik muslim dan non-muslim.

Tentu, pengunaan metode maupun alat itu mesti selaras dengan prinsipprinsip tazkiyah nafs, terutama perihal tujuan dan indikator kesehatan jiwa. Prinsip-prinsip itu diperlukan sebagai bentuk diferensiasi umat islam dari umat lain. Hilangnya sisi unik umat islam dan meleburnya dalam karakter umat lain sejatinya beresiko pada identitas keumatannya. Manusia, dalam konsep ilmu kejiwaan islam, disebut sehat manakala telah memiliki dinamika jiwa muthmainnah yang menunjukkan ketenangan pribadinya meski ketenangan itu sendiri memiliki kualitas dan dimensinya sendiri. Pribadi yang mencapai dinamika jiwa muthmainnah dalam ilmu tasawwuf sering diistilahkan dengan insan kamil (manusia sempurna). Di sini, para sarjana ilmu kejiwaan muslim memang berbeda pendapat mengenai indikator manusia sempurna. Perbedaan itu bermula pada sifat spiritual pengalaman masingmasing pribadi yang dianggap telah mencapai derajat insan kamil. Meski begitu, seorang pribadi menjadi sempurna, menurut Ibn Qayyim (2004: 27) dengan dua hal, yaitu: kesempurnaan pribadi (alkamal nafsi) dan menyempurnakan oranglain (ikmal al-ghair). Jelasnya, kesempurnaan pribadi meliputi dua hal, yakni: iman dan amal (saleh), sedangkan menyempurnakan orang lain mencakup dua hal pula, yaitu: saling menasihati dalam kebaikan (mendidik) dan saling menasehati dalam kesabaran. Dari sini, manusia sempurna (insan kamil) adalah pribadi yang memiliki kualitas ilmu dan kualitas amal secara seimbang, dan mampu menularkan kualitas 
itu pada orang lain. Kualitas ilmu ditandai dengan iman, yang mencakup ranah: kognitif dan konatif. Kualitas amal ditandai dengan amal saleh, yang mencakup ranah psikomotorik. Karenanya, pertemuan indikator kesehatan jiwa dan pencapaian tujuan pendidikan karakter adalah mungkin.

Tujuan tazkiyah nafs itu sendiri adalah pengembangan karakter manusia. Tazkiyah, menurut Ahmad (dalam Pickhen, 2005: 94), dapat bermakna mengembangkan karakter, pemikiran dan perilaku. Ia dimaknai mencetak seluruh perbuatan individu agar terbebas dari dari semua yang buruk, yang tidak sehat dan yang tidak dikehendaki di mata Allah, dan memberinya semua perhiasan yang Allah menghendakinya tumbuh subur dalam kehidupan manusia. Karena itu, tazkiyah, dapat dibahasakan, sebagai "kesimpulan" dari semua konsep pembangunan karakter. Di sinilah, titik singgung antara kesehatan jiwa dan pendidikan karakter.

Simpulan Beberapa hal yang dapat disimpulkan dalam penelitian ini adalah sebagai berikut: (1) nafs adalah jiwa manusia (self), yang merupakan pertemuan antara unsur ruh dan jasad dari entitas manusia; (2) jiwa manusia, dalam konsep keilmuan islam, mengalami tiga dinamika, yaitu: (a) nafs ammarah bi al-su', yang merupakan dinamika terendah), (b) nafs lawwamah, dan (c) nafs muthmainnah, yang menjadi dinamika jiwa tertinggi; (3) dinamika jiwa tertinggi memiliki kualitas ketenangan (ithmi`nan), yang dalam aspek tertentu melahirkan karakter; (4) konsep karakter bertemu dengan konsep adab pada wilayah interaksi intrapersonal dan interaksi antarpersonal, dan berpisah pada wilayah interaksi spiritual dengan Allah; (5) kualitas karakter dapat diupayakan dengan penyehatan jiwa (tazkiyah nafs), yang dapat dicapai melalui berbagai metode, media dan alat ukur temuan sarjana muslim dan nonmuslim, dengan dengan tetap mengacu pada indikator kesehatan jiwa dan tujuan tazkiyah nafs; (7) indicator kesempurnaan pribadi insan kamil mencakup ranah kognitif, konatif, psikomotorik (maupun motorik) yang juga merupakan titik temu dengan ranah pendidikan karakter. Beberapa hal yang dapat disarankan dalam 
penelitian ini adalah: (1) bagi peneliti berikutnya yang tertarik untuk membandingkan temuan dalam penelitian ini dengan penelitian lain, sebagai bahan untuk mencari kecenderungan umum, dapat melakukan penelitian yang sama dengan ranah atau sumber penelitian yang berbeda, (2) penelitian berikutnya dapat menggali dan mengorisinalisasi konsep-konsep ilmu tasawwuf dalam rangka menemukan teori, indikator dan alat ukur yang signifikan, valid dan applicable (3) penelitian ini perlu diperlebar dengan penelitian kualitatif, terutama dalam aspek pengaruh kesehatan jiwa terhadap karakter, sehingga signifikansi penelitian ini akan semakin nyata.

\section{Catatan Akhir}

Dalam pandangan Zakiah Daradjat hal yang mempengaruhi Kesehatan mental seorang manusia ada 4 faktor antara lain: perasaan, pikiran/ kecerdasan, kelakuan dan kesehatan badan. Kesehatan mental ini kemudian sangat berperan dalam proses Pendidikan, terlebih lagi Pendidikan karakter. Oleh karenanya terapi yang dapat dilakukan terhadap orang yang mengalami gangguan mental antara lain: terapi individu, terapi jiwa (psikoterapi) dan terapi agama. Secara lebih khusus kemudian terapi agama memiliki fungsi sebagai terapi sangat bermanfaat bagi kesehatan mental seseorang. Enam macam pokok keimanan tersebut ialah: iman kepada Allah, iman kepada malaikat, iman kepada kitab-kitab suci, iman kepada Rasul-rasul, iman kepada hari kiamat dan iman kepada takdir.

\section{Daftar Pustaka}

Al-Ahmad, A. A. 2001. Al-Tariq ila al-Sibhab al-Nafsiab; 'Inda Ibn Qayyim wa 'Ilm al-Nafs. Riyad: Dar al-fadilah Al-Azhari.

Ancok, J. \& Suroso, F. N. 1995. Mukhtasar Minhaj Al-Qasidin. Beirut: Dar Al-Bayan

Arabi, Ruslani. 2000. Masyarakat Kitab dan Dialog Antar Agama; Studi atas Pemikiran Mubammad Arkoun. Yogyakarta: Benteng Budaya.

Ari H. Gunawan. 1995. Kebijakan-kebijakan Pendidikan di Indonesia. Jakarta: Rineka Cipta 
Arikunto, Suharsimi. 2006. Psikologi Islami: Solusi Islam atas Problem Problem Psikologi. Yogyakarta: Pustaka Pelajar

Baharudin. 2004. Prosedur Penelitian: Sebuah Pendekatan Praktik. Jakarta: Penerbit Rineka Cipta.

Bainar. 1997. Kiat Sukscs Wanita Indonesia. Jakarta: Perkasa Pres.

Bastaman, H. D. 1997. Paradigma Psikologi Islam: Studi Tentang Elemen Psikologi dari Al-Qur'an. Yogyakarta: Pustaka Pelajar.

Bukhari. 1999. Integrasi Psikologi dengan Islam: Menuju Psikologi Islami.

Yogyakarta: Pustaka Pelajar.

Daradjat, Z. 1990. Kesehatan Mental. Bandung: Penerbit Pustaka Setia

Dewi, K. S. 2010. Kebahagiaan. Jakarta: YPI Ruhama.

Hadi, S. 2000. Psikologi Agama; Memahami Pengaruh Agama Terhadap Perilaku Manusia. Jakarta: Lembaga Peneliti UIN Syarif Hidayatullah.

Hadi, S. 2007. Metodologi Research. Yogyakarta: Fakultas Psikologi UGM.

Hasan Langgulung. 1986. Teori-teori Kesehatan mental. Jakarta: Pustaka Al Husna.

Hasan, A. B. P. 2008. Islam Spiritual: Cetak Biru Keserasian Eksistensi. Malang: UIN Malang Press.

Ichwan, N. 2002. Psikologi Perkembangan Islami. Jakarta: Raja Grafindo Persada.

Kartono, K., et. al. 1989. Memahami Bahasa al-Qur'an: Refleksi atas Persoalan Linguistik. Yogyakarta: Pustaka Pelajar.

Kartono, Kartini. 2000, Hygiene Mental. Bandung: Mandar Maju.

Nasir, M. 1990. Metode Penelitian. Jakarta: Graha Indonesia.

Nugroho, M. A. 2011. Konsep Jiwa dalam Al-Qur'an; Solusi Qur'ani untuk penciptaan kesehatan Jiwa dan Implikasinya Terhadap Pendidikan Islam. Tesisi. Yogyakarta: UIN Sunan Kalijaga

Pickhen, G. N. 2005. The Concept of Tazkiyat al-Nafs in Islam in the Light of the Works of al-Härith al-Mubäsibi. Tt: University of Leads.

Rajih, A. I. 1968. Usul Tlm al-Nafs. Kairo: Dar al-Katib. 
Said, M. 2011. Pendidikan Karakter di Sekolah. Surabaya: Jaringpena.

Syaharia, A. R. H. 2008. Stigma Ganguan Jiwa Perspektif Mental Islam. Skripsi. Yogyakarta: UIN Sunan Kalijaga.

Tebba, Sudirman. 2005. Sehat Labir Batin. Jakarta: PT. Serambi Ilmu Semesta.

Tim Penyusun Pusat Pembinaan Pengembangan Bahasa. 1994. Kamus Besar Bahasa Indonesia. Jakarta: Balai Pustaka.

Yaumi, M. 2014. Pendidikan Karakter: Landasan, Pilar dan Implementasi. Jakarta: Prenadamedia Grup.

Zakiah Daradjat. 1993. Imu Jiwa Agama. Jakarta: Bulan Bintang. 